Velkomin til

Norơurlandaráôs

- starf og starfshættir

(11) Norðurlandaráð 


\section{Velkomin til Norðurlandaráðs}

- starf og starfshættir

ANP 2017:715

ISBN 978-92-893-4875-1 (PRINT)

ISBN 978-92-893-4876-8 (PDF)

ISBN 978-92-893-4942-O (EPUB)

http://dx.doi.org/10.6027/ANP2017-715

(c) Norðurlandaráð

Umbrot: Louise M. Jeppesen

Prentun: Rosendahls

Printed in Denmark

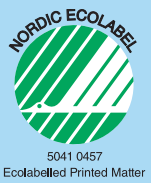

\section{Norrænt samstarf}

Norræna samstarfið er eitt umfangsmesta svæðasamstarf í heiminum. Samstarfið nær til Danmerkur, Finnlands, Íslands, Noregs og Svípjóðar auk Álandseyja, Færeyja og Grænlands. Norræna samstarfið er pólitískt, efnahagslegt og menningarlegt og skiptir miklu í evrópsku og alpjóðlegu samstarfi. Í norrænu samstarfi er unnið að pví að styrkja stöðu Norðurlanda í sterkri Evrópu. Með norrænu samstarfi er unnið að pví að efla norræna og svæðisbundna hagsmuni í alpjóðlegu umhverfi. Sameiginleg gildi landanna styrkja stöðu Norðurlanda og skipa peim meðal peirra svæða í heiminum par sem nýsköpun og samkeppnishæfni er mest.

\section{Norðurlandarád}

Ved Stranden 18

DK-1061 København K

www.norden.org

Sækja útgefið efni: www.norden.org/nordpub 
Velkomin til

Norơurlandaráôs

- starf og starfshættir

(11) Norðurlandaráð 


\section{Efnisyfirlit}

Velkomin til Norðurlandaráðs

Um Norðurlandaráð

Norrænt notagildi

Verðlaun Norðurlandaráðs

Svansmerkið

Skipulag og uppbygging

Norðurlandaráðsping

Forseti og varaforseti

Forsætisnefndin

Nefndir

Alpjóðlegt samstarf $\quad 20$

Skrifstofa Norðurlandaráðs $\quad 23$

Landsdeildir

Flokkahópar

Ritarafundir 
Starfsárið og starfshættir $\quad 27$

Gerð fjárhagsáætlunar: Norræna ráðherranefndin 29

Formennskuáætlun 30

Fjárhagsáætlun og fjármál $\quad 31$

Fjárhagsáætlanir landsdeildanna 31

Styrkir til flokkahópa $\quad 31$

Mál og afgreið̌sla peirra $\quad 32$

Pingmanna-/nefndartillögur (A-mál) 33

Ráðherranefndartillögur (B-mál) 34

Greinargerðir og skýrslur (C-mál) $\quad 35$

Álit/svör (D-mál) 35

Fyrirspurnir (E-mál) $\quad 36$

Pólitískt samrád $\quad 37$

Ákvarðanir 38

Norræna ráŏherranefndin $\quad 41$

Skrifstofa ráðherranefndarinnar $\quad 42$

Skrifstofur landsdeilda Norðurlandaráðs $\quad 45$ 


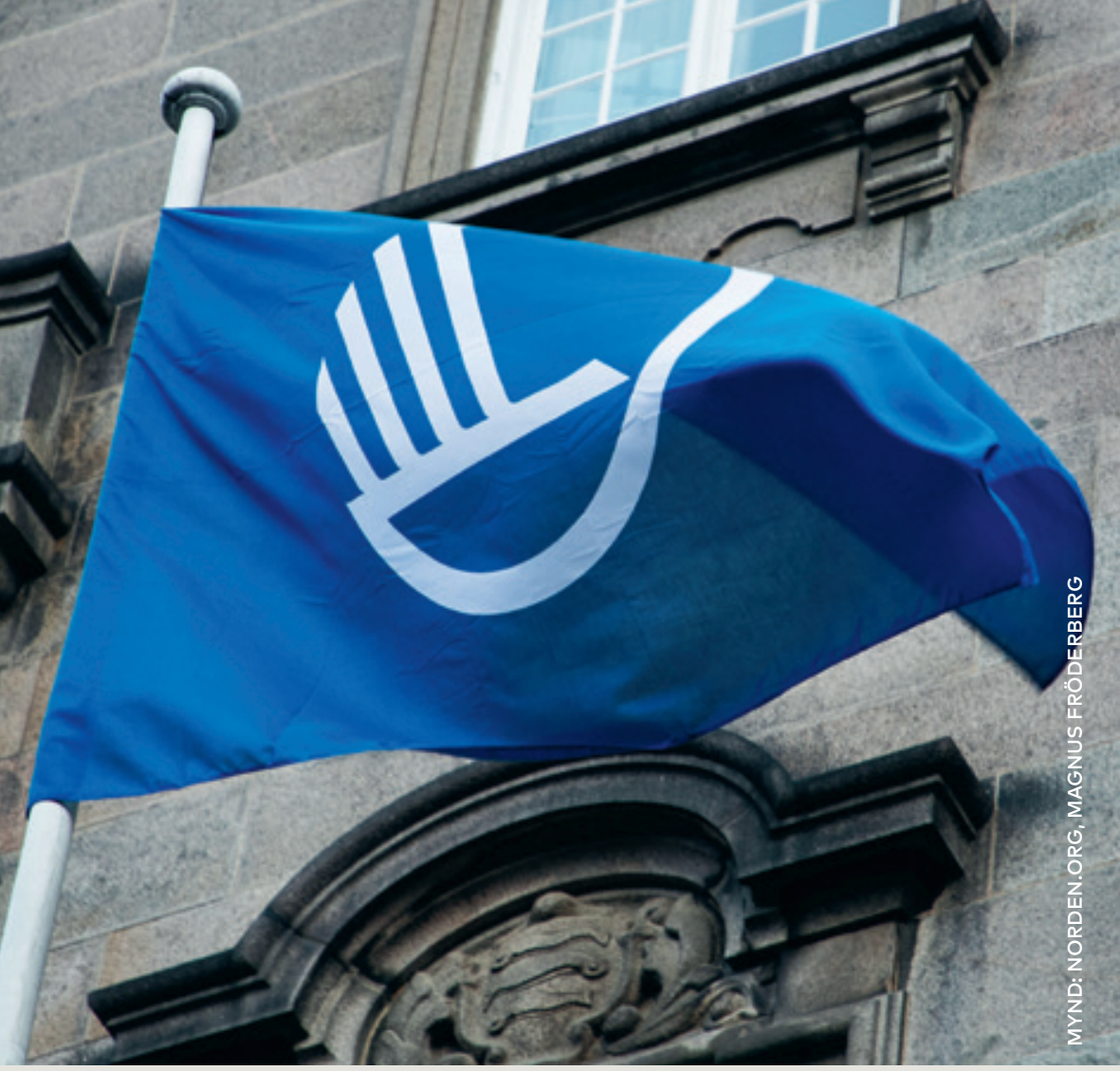

Frekari fróðleik má nálgast á heimasíðunni www.norden.org, en par er einnig að finna frekari upplýsingar um norrænt samstarf og ítarlegri umfjöllun um Norðurlandaráð. 


\section{Velkomin til Norðurlandaráðs}

Pessi bæklingur er stutt kynning á starfi Norðurlandaráðs. Kaflarnir eru hafðir stuttir og par koma einungis fram allra nauðsynlegustu upplýsingar. Frekari fróðleik má nálgast á heimasíðunni www.norden.org, en par er einnig að finna frekari upplýsingar um norrænt samstarf og ítarlegri umfjöllun um Norðurlandaráð. Par er einnig hægt að gerast áskrifandi að norrænum fréttabréfum. 



\section{Um Norðurlandaráð}

Norðurlandaráð var stofnað árið 1952 sem

samstarfsvettvangur pjóðpinga og ríkisstjórna Norðurlanda, sem vildu í kjölfar seinni heimsstyrjaldar koma á nánara samstarfi. 87 fulltrúar frá Danmörku, Finnlandi, Íslandi, Noregi og Svípjóð og frá Færeyjum, Grænlandi og Álandseyjum eru skipaðir af pjóðpingum landanna samkvæmt tillögum stjórnmálaflokkanna. Ekki eru beinar kosningar til Norðurlandaráðs. Samapingin í Finnlandi, Noregi og Svípjóð hafa, auk Norðurlandaráðs æskunnar, áheyrnarrétt í Norðurlandaráði.

Norðurlandaráð og Norræna ráðherranefndin eiga að vinna sameiginlega að norrænum lausnum sem hafa skýr jákvæð áhrif og norrænt notagildi (sjá eftirfarandi) fyrir alla Norðurlandabúa. pað gerir Norðurlandaráð fyrst og fremst með pví að leggja fram tillögur og hafa áhrif á og veita norrænu ríkisstjórnunum ráðgjöf með yfirlýsingum og fyrirspurnum. Helstu verkfæri fulltrúanna eru tillögur og fyrirspurnir sem hægt er að beina til Norrænu ráðherranefndarinnar eða til einnar eða fleiri ríkisstjórna Norðurlanda.

Norðurlandaráð á náið samstarf við pjóðping og fjölda alpjóðlegra og svæðisbundinna pingmannasamtaka bæði innan og utan Norðurlanda.

Starf í Norðurlandaráði byggist á Helsingforssamningnum frá árinu 1962, ásamt starfsreglum Norðurlandaráðs. 


\section{Norrænt notagildi}

Reglan um norrænt notagildi er mikilvæg í norrænu samstarfi. Meginatriði hennar eru

- að sameiginlegar norrænar lausnir hafi meiri áhrif en sömu aðgerðir í hverju landi fyrir sig

- að efla og próa norræna samkennd

- að auka norræna færni og samkeppnishæfni

- að efla norræn áhrif á alpjóðavettvangi.

Norrænt samstarf beinir sjónum að málaflokkum par sem samnorrænar aðgerðir skapa virðisauka fyrir hvert land fyrir sig og íbúa peirra. Árangur samstarfsins birtist - og á að birtast - í lífi og starfi fólks og fyrirtækja á Norðurlöndum. Samstarfið hefur m.a. leitt til sameiginlegs norræns vinnumarkaðar, vegabréfasambands og fjölda sameiginlegra félagslegra ákvæða. Auk pess hafa íbúar Norðurlanda lengi getað sest að og stundað nám og rannsóknir alls staðar á Norðurlöndum jafnfætis ríkisborgurum viðkomandi lands.

Umhverfis-, loftslags- og orkumál og rannsóknir, menntun og nýsköpun, að tryggja opin Norðurlönd og aukinn sýnileiki eru mikilvæg atriði í norrænu samstarfi sem miðar að pví аð Norðurlönd verði áfram í fremstu röð í hnattvæddum heimi. 


\section{Verơlaun Norðurlandaráðs}

Norðurlandaráð veitir á hverju ári fimm verðlaun. Við árlega verðlaunaafhendingu eru veitt bókmenntaverðlaun, tónlistarverðlaun, kvikmyndaverðlaun, barna- og unglingabókaverðlaun og náttúru- og umhverfisverðlaun.

Verðlaunum Norðurlandaráðs er ætlað að vekja áhuga almennings á norrænum bókmenntum, tungumálum, tónlist og kvikmyndum. Náttúru- og umhverfisverðlaunin eru veitt norrænu fyrirtæki, samtökum eða einstaklingi sem hefur með fyrirmyndarvinnubrögðum gert náttúru- og umhverfissjónarmið að föstum pætti í rekstri sínum eða starfi, eða hefur á annan hátt unnið mikilsvert starf í págu náttúru og umhverfis. Hver verðlaun nema 350.000 danskra króna. 
$\leftarrow$ Katarina Frostenson frá Svípjóð hlaut

bókmenntaverðlaun Norðurlandaráðs árið

2016 fyrir ljóðasafnið „Sånger och formler".

\section{Svansmerkið}

Svansmerkið á uppruna sinn í svönunum fimm sem birtust fyrst á veggspjaldi vegna dags Norðurlanda árið 1936 sem gert var út frá ljóðinu „Svanerne fra Norden” eftir Hans Hartvig Seedorff-Pedersen.

Árið 1956 voru gefin út frímerki á Norðurlöndum par sem myndefnið var fimm svanir, útfært með ólíkum hætti. Árið 1985 urðu svanirnir fimm síðan innblástur fyrir nýtt tákn fyrir opinbert norrænt samstarf sem finnski listamaðurinn Kyösti Varis hannaði fyrir Norrænu ráðherranefndina og Norðurlandaráð. Vængfjaðrirnar átta í svansmerkinu tákna norrænu ríkin fimm, Danmörku, Finnland, Ísland, Noreg og Svípjóð, ásamt Færeyjum, Grænlandi og Álandseyjum.

Árið 1989 var svansmerkið notað sem fyrirmynd að norræna umhverfismerkinu sem nú er vel pekkt. Markmiðið var að gefa norrænum neytendum kost á að velja bestu fáanlega vöru á markaði út frá umhverfissjónarmiði. 


\section{Skipulag og uppbygging}

Pingið, forsætisnefndin og nefndir Norðurlandaráðs eru pólitískur samstarfsvettvangur Norðurlandaráðs. Pingið kýs einnig eftirlitsnefnd og kjörnefnd.

Kjör fulltrúa í Norðurlandaráði fer fram samkvæmt eftirfarandi skiptireglu:

Landsdeild Danmerkur

- Færeyjar

- Grænland

Landsdeild Finnlands

- Álandseyjar

Landsdeild Íslands

Landsdeild Noregs

Landsdeild Svípjóðar

20

Samtals

87

Fulltrúar Færeyja, Grænlands og Álandseyja eiga sæti annars vegar í dönsku og hins vegar finnsku landsdeildinni.

Stjórnsýslan er í höndum skrifstofu Norðurlandaráðs, skrifstofa landsnefndanna, skrifstofa flokkahópanna og ritarafundar. Sjá nánar á bls. 23-25. 


\section{Norðurlandaráðsping}

Ping Norðurlandaráðs fer með æðsta ákvörðunarvald Norðurlandaráðs, sampykkir fjölda ákvarðana (tilmæla) á árlegum pingum sínum, leggur fram yfirlýsingar til ráðherranefndarinnar eða ríkisstjórna Norðurlanda. Pingið kýs forseta og varaforseta Norðurlandaráðs, kýs um skipan nefnda og velur stund, stað og málefni fyrir næsta aðalping.

Árlegt aðalping Norðurlandaráðs er haldið i 44. viku (október/nóvember) til skiptis í höfuðborgum Norðurlanda í pví landi sem fer með formennsku í eftirfarandi röð: Danmörk, Finnland, Noregur, Svípjóð og Ísland. Aukaping koma saman ef forsætisnefnd ákveður slíkt, eða ef a.m.k. tvær ríkisstjórnir eða tuttugu og fimm fulltrúar óska eftir pví.

Á Norðurlandaráðspingi sitja 87 kjörnir fulltrúar ásamt breytilegum fjölda ráðherra, en einungis kjörnir fulltrúar hafa atkvæðisrétt. Pingfundirnir eru opnir.

Pingfundum er stjórnað af forseta eða öðrum fulltrúa í forsætisnefnd. Í upphafi pingsins sampykkja pingmenn dagskrá ásamt reglum um pingsköp, samkvæmt tillögu forsætisnefndar.

Fastur liður á dagskrá pingsins er leiðtogafundur með pátttöku forsætisráðherra Norðurlanda. Hér geta fulltrúarnir rætt beint við forsætisráðherrana málefni sem eru ofarlega á baugi á grundvelli tiltekins pema sem ákveðið er fyrirfram. Annar fastur liður á dagskránni er 
fyrirspurnatími samstarfsráðherranna en pá geta fulltrúar í Norðurlandaráði lagt fyrirspurnir beint fyrir ráðherra ríkjanna fimm og Grænlands, Færeyja og Álandseyja.

Atkvæðagreiðsla er opin. Tillögur sem atkvæði eru greidd um, eiga að vera orðaðar pannig að hægt sé að svara peim játandi eða neitandi. Pingið er ákvarðanabært pegar 44 fulltrúar eða varamenn eru viðstaddir.

Vinnutungumál Norðurlandaráðs eru skrifuð og töluð danska, norska og sænska en öll mikilvæg vinnuskjöl eru pýdd yfir á finnsku og íslensku. Á pingunum er samtímatúlkað til og frá finnsku og íslensku og ensku eftir pörfum. Á nefndarfundum er hægt að túlka til og frá finnsku og íslensku eftir pörfum.

\section{Forseti og varaforseti}

Forseti og varaforseti Norðurlandaráðs næsta almanaksárs eru kjörnir á árlegu aðalpingi Norðurlandaráðs. Forseti og varaforseti eru kjörnir úr röðum fulltrúa pess lands par sem næsta aðalping fer fram. Löndin skiptast á um að skipa embættið í eftirfarandi röð: Finnland, Noregur, Svípjóð, Ísland og Danmörk. 


\section{Forsætisnefndin}

Forsætisnefnd Norðurlandaráðs fer með ákvarðanavald á milli hinna árlegu pinga. Forsætisnefndin stjórnar og samræmir samstarf innan Norðurlandaráðs, ber ábyrgð á helstu pólítískum og stjórnsýslulegum málefnum, semur framkvæmdaáætlanir og fjárhagsáætlanir og sér um meginatriði í utanríkis- og öryggismálum, ásamt pví að sjá um alpjóðlegt samstarf Norðurlandaráðs.

Forsætisnefndin er staðgengill pingsins milli pinga og getur lagt fram yfirlýsingar eða tilmæli. Í forsætisnefnd eiga sæti forseti og varaforseti ásamt 13 pingfulltrúum. Öll lönd og flokkahópar eiga fulltrúa í forsætisnefnd.

Forsætisnefndin (og fagnefndirnar) geta haft undirnefndir eða starfshópa, talsmenn/áheyrnarfulltrúa og skýrslugjafa í afmörkuðum verkefnum í skemmri eða lengri tíma. Dæmi um petta er hópur talsmanna flokkahópanna um fjárhagsáætlun sem á samráð við ráðherranefndina um norrænu fjárhagsáætlunina og fastir skýrslugjafar nefndanna, t.d. í málefnum sem varða ESB, stjórnsýsluhindranir, neytendamál, orkumál eða aðra málaflokka sem nefndirnar kjósa að veita forgang.

\section{Nefndir}

Pólitískt samstarf innan fagsviða fer fyrst og fremst fram í fjórum fagnefndum Norðurlandaráðs og í forsætisnefnd, en hún stjórnar starfi nefndanna. Nefndirnar fjalla um mál 
á sínu fagsviði: pingmanna- og nefndartillögur, ráðherra- og ríkisstjórnartillögur, greinargerðir, álit, svör o.fl.

Yfirleitt eru nefndarfundir lokaðir almenningi, en nefndirnar geta ákveðið hvort fundirnir séu lokaðir eða ekki. Pær geta t.d. boðið gestum til að gera grein fyrir tilteknu málefni. Einnig er hægt að sækja um að fá að koma fyrir nefndirnar í samræmi við reglur um áheyrnarrétt.

Nefndir Norðurlandaráðs eru eftirfarandi:

- Norræna bekkingar- og menningarnefndin beinir sjónum að menningu, rannsóknum og menntun, grunn- og framhaldsskólum, fullorðinsfræðslu og alpýðufræðslu - par á meðal málum sem snerta tungumálasamstarf, nýmiðla, færnipróun og nýsköpun á sviði menntamála og ípróttamál.

- Norræna velferðarnefndin fæst við norræna velferðarlíkanið. Nefndin leitast við að finna sjálfbærar efnahagslegar lausnir á sviðum sem varða umönnun barna, ungmenna og eldri borgara, fatlanir ásamt áfengis-og fíkniefnamálum. Á dagskrá nefndarinnar eru einnig jafnréttismál, réttindi borgaranna, lýðræði, mannréttindamál og barátta gegn glæpum. Samlögun, fólksflutningar og málefni flóttamanna heyra einnig undir velferðarnefndina ásamt húsnæðismálum og málefnum frumbyggja á Norðurlöndum. 
- Norræna sjálfbærninefndin leggur áherslu á umhverfisog náttúruvernd, náttúruauðlindir - par á meðal nýtingu náttúruauðlinda í landbúnaði, sjávarútvegi og skógrækt. Nefndin fjallar einnig um loftslagsmál, réttindi neytenda, fiskveiðistjórnun, landbúnaðarmál, matvæli, kjarnorkuöryggi, líffræðilega fjölbreytni og sjálfbærni.

- Norræna hagvaxtar- og próunarnefndin fjallar um málefni sem snerta vinnumarkað og vinnuvernd, atvinnulíf, viðskipti, iðnað, orkumál, baráttu gegn stjórnsýsluhindrunum, samgöngur og öryggi i samgöngumálum. Nefndin fjallar einnig um mál sem tengjast fjármála- og efnahagsstefnu - par á meðal starfsskilyrði rannsókna, framleiðslu og viðskipta, og í framhaldi af pví frjálsa för á mörkuðum og vinnumörkuðum á Norðurlöndum ásamt svæða- og skipulagsmálum, samskiptum og upplýsingatækni.

Allar nefndirnar leitast við að efla samstarf við ESB og fylgjast pví með afgreiðslu mála sem skipta norrænt samstarf máli.

\section{Eftirlitsnefndin}

Eftirlitsnefndin fylgist fyrir hönd pingsins með starfsemi sem fjármögnuð er úr sameiginlegum sjóðum Norðurlanda. Eftirlitsnefndin getur beint yfirlýsingum til forsætisnefndar um hvernig túlka beri Helsingforssamninginn, aðra samninga um norrænt samstarf, starfsreglur Norðurlandaráðs og um önnur innri málefni. Öll löndin skulu eiga fulltrúa í 
eftirlitsnefndinni, en í henni sitja sjö fulltrúar og jafnmargir varamenn.

\section{Kjörnefnd}

Kjörnefnd undirbýr og leggur fram tillögur að kjöri sem fer fram á pinginu. Í kjörnefnd eiga sæti sjö fulltrúar.

\section{Stjórnsýs/uhindranahópur}

Stjórnsýsluhindranahópurinn er óformlegur starfshópur sem heyrir undir Norrænu hagvaxtar- og próunarnefndina. Í hópnum eiga sæti einn eða fleiri fulltrúar nefndarinnar og forsætisnefndar. Markmið starfshópsins er að hlutast til um og samræma starf nefndanna og forsætisnefndarinnar gegn stjórnsýsluhindrunum, og tengja saman starf Norðurlandaráðs og Stjórnsýsluhindranaráðs Norrænu ráðherranefndarinnar að afnámi stjórnsýsluhindrana, en par á einnig sæti fulltrúi Norðurlandaráðs.

\section{Alpjóðlegt samstarf}

Norðurlandaráð á náið samstarf við fjölda svæðisbundinna pinga og pingmannasamtaka utan Norðurlanda.

Forsætisnefndin ber meginábyrgð á alpjóðasamskiptum, en fagnefndirnar fjórar eru einnig virkar í alpjóðlegu starfi. Á árinu 2017 mun forsætisnefndin uppfæra stefnumörkun Norðurlandaráðs í alpjóðamálum hvað varðar starf útávið.

Vegna landfræðilegrar legu Norðurlanda í Norður-Evrópu og Norður-Atlantshafi er eðlilegt að Norðurlandaráð eigi einkum samskipti við pjóðping á pessu svæði. pau 
felast m.a. í samstarfi við aðila á Eystrasaltssvæðinu, Norðurskautssvæðinu, Barentssvæðinu og við norðlægu víddina. Norðurlandaráð vill gjarnan láta meira til sín taka gagnvart ESB í málaflokkum sem varða samnorræna hagsmuni, ekki síst gagnvart norrænum fulltrúum á Evrópupinginu. Á árinu 2017 mun Norðurlandaráð ráða starfsmann sem mun bera sérstaka ábyrgð á pessum tengslum.

Norðurlandaráð hefur árum saman átt samstarf við rússneska pingmenn, bæði á svæðum í Norðvestur-Rússlandi og einnig við Dúmuna og Sambandsráðið í Moskvu. Innlimun Krímskagans dró úr samskiptunum en pó eru enn tengs। við rússneska pingmenn. Allt frá pví að Eystrasaltspingið var stofnað hafa verið náin tengsl milli pess og Norðurlandaráðs. Eystrasaltspingið er nánasti samstarfsaðili Norðurlandaráðs.

Norðurlönd eru hluti af Norðurskautssvæðinu. Meðal forgangsmála í norrænu samstarfi er samstarf við Vestnorræna ráðið og við grannlönd Norðurlanda í vestri, einkum Kanada.

Norðurlandaráð hefur samband við önnur svæði í Evrópu, par á meðal Evrópuráðið og Benelúxpingið. Á Balkanskaga og í löndum sem áður tilheyrðu Sovétríkjunum er einnig áhugi á að læra af reynslu Norðurlanda af svæðasamstarfi. 


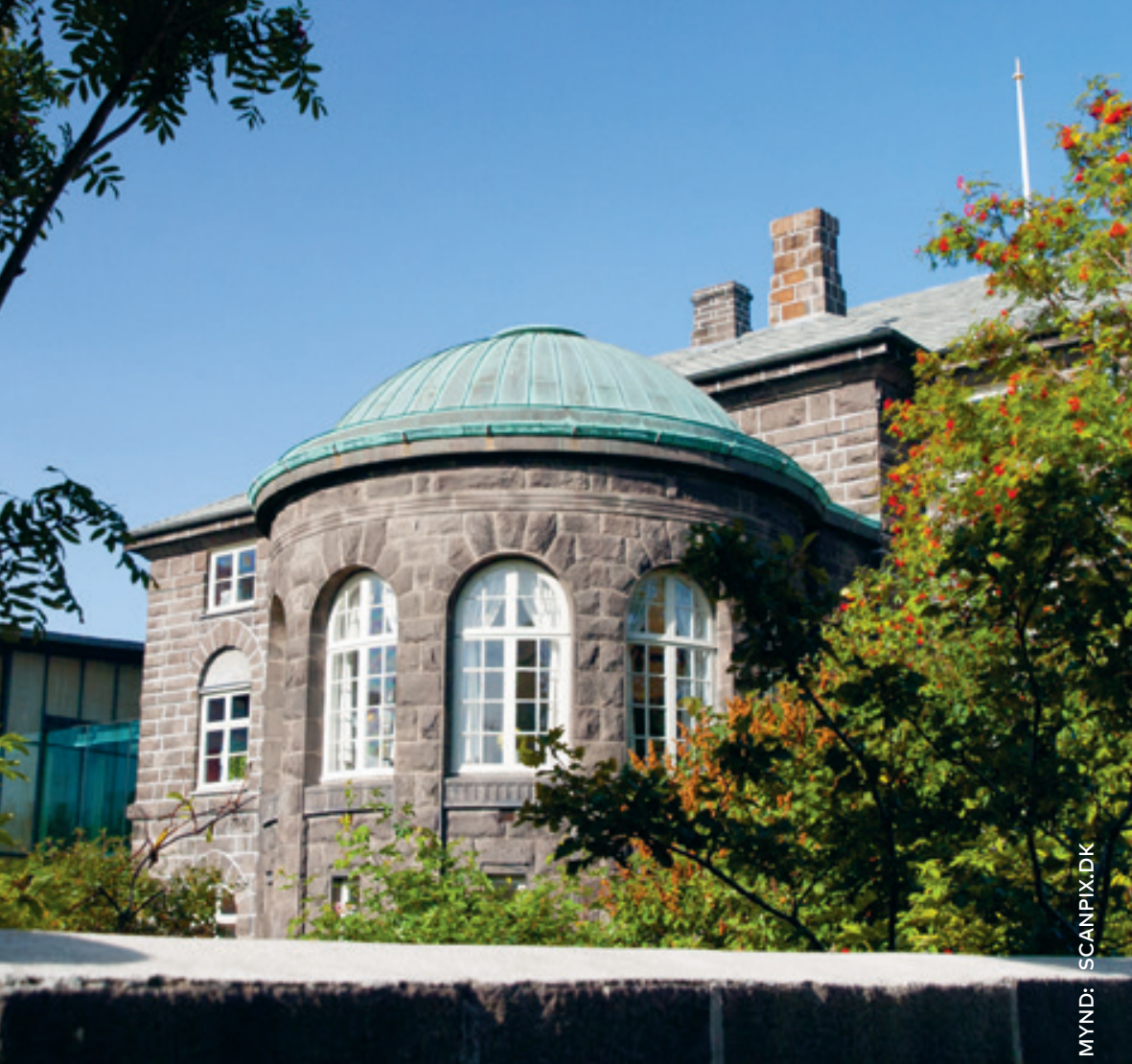

Norrænu löndin, að Færeyjum, Grænlandi og

Álandseyjum meðtöldum, hafa hvert sína landsdeild

i Norðurlandaráði. Myndin er af Alpingishúsinu í

Reykjavík. 


\section{Skrifstofa Norðurlandaráðs}

Skrifstofa Norðurlandaráðs hefur aðsetur á sama stað og Norræna ráðherranefndin og Norræni menningarsjóðurinn í Norðurlandahúsinu í miðborg Kaupmannahafnar. Á skrifstofunni starfa um pað bil 15 manns frá öllum Norðurlöndum. Daglegum störfum skrifstofunnar er stýrt af framkvæmdastjóra Norðurlandaráðs.

Skrifstofa Norðurlandaráðs undirbýr og fylgir eftir málum sem fjallað er um í forsætisnefnd, fagnefndum og öðrum stofnunum og ber ábyrgð á samskiptum við Norrænu ráðherranefndina, hagsmunaaðila, alpjóðleg samtök og tengslum við skrifstofur landsdeilda og flokkahópa.

\section{Landsdeildir}

Norrænu löndin, að Færeyjum, Grænlandi og Álandseyjum meðtöldum, hafa hvert sína landsdeild í Norðurlandaráði. Landsdeildirnar sjá til pess að ákvörðunum teknum í Norðurlandaráði og ráðherranefndinni sé fylgt eftir í löndunum. Landsdeildirnar hafa eigin skrifstofur í pjóðpingum landanna. Meginverkefni skrifstofa landsdeildanna er að vera kjörnum fulltrúum Norðurlandaráðs til aðstoðar með:

- hagnýt atriði

- fundargögn

- samningu tillagna og/eða fyrirspurna o.fl. 
Skrifstofurnar greina frá starfi Norðurlandaráðs hver í sínu landi og eru auk pess virkar í undirbúningi og framkvæmd nefndarfunda, málpinga, umsagnarferla, pinga o.fl.

\section{Flokkahópar}

Kjörnir fulltrúar í Norðurlandaráði geta myndað flokkahópa. Í flokkahópi verða að vera a.m.k. fjórir pingfulltrúar frá eigi færri en tveimur löndum.

Flokkahóparnir fá styrki til starfsemi sinnar í Norðurlandaráði samkvæmt reglum sem forsætisnefndin setur.

Í Norðurlandaráði eru eftirfarandi fimm flokkahópar:

- Flokkahópur jafnaðarmanna

- Flokkahópur miðjumanna

- Flokkahópur hægrimanna

- Flokkahópur vinstrisósíalista og grænna

- Norrænt frelsi

Nánari upplýsingar um flokkahópana er að finna á www.norden.org.

Fulltrúar og flokkar sem ekki tilheyra neinum flokkahópi fá styrki samkvæmt reglum sem forsætisnefnd setur. 
Flokkahóparnir hafa eigin skrifstofur og ráða sjálfir sitt aðstoðarfólk. Hlutverk flokkahópanna er m.a. að

- semja fyrirspurnir og pingmannatillögur

- undirbúa kjör í Norðurlandaráði

- samræma pólitíska afstöðu innan hópsins í málefnum sem eru til umfjöllunar

- samræma og setja fram pólitíska afstöðu hópsins

- samræma samstarf við pingflokka og stjórnmálaflokka í einstökum löndum

- halda sambandi við ríkisstjórnir landanna og tilsvarandi flokkahópa í ESB og á öðrum alpjóðlegum vettvangi

- hafa samráð við borgara og samtök á Norðurlöndum eftir atvikum.

\section{Ritarafundir}

Ritarafundi sitja framkvæmdastjóri Norðurlandaráðs og starfsmenn skrifstofanna, landsdeilda og flokkahópa. Ritarafundurinn undirbýr fundi forsætisnefndar og fjallar um önnur sameiginleg hagsmunamál. 


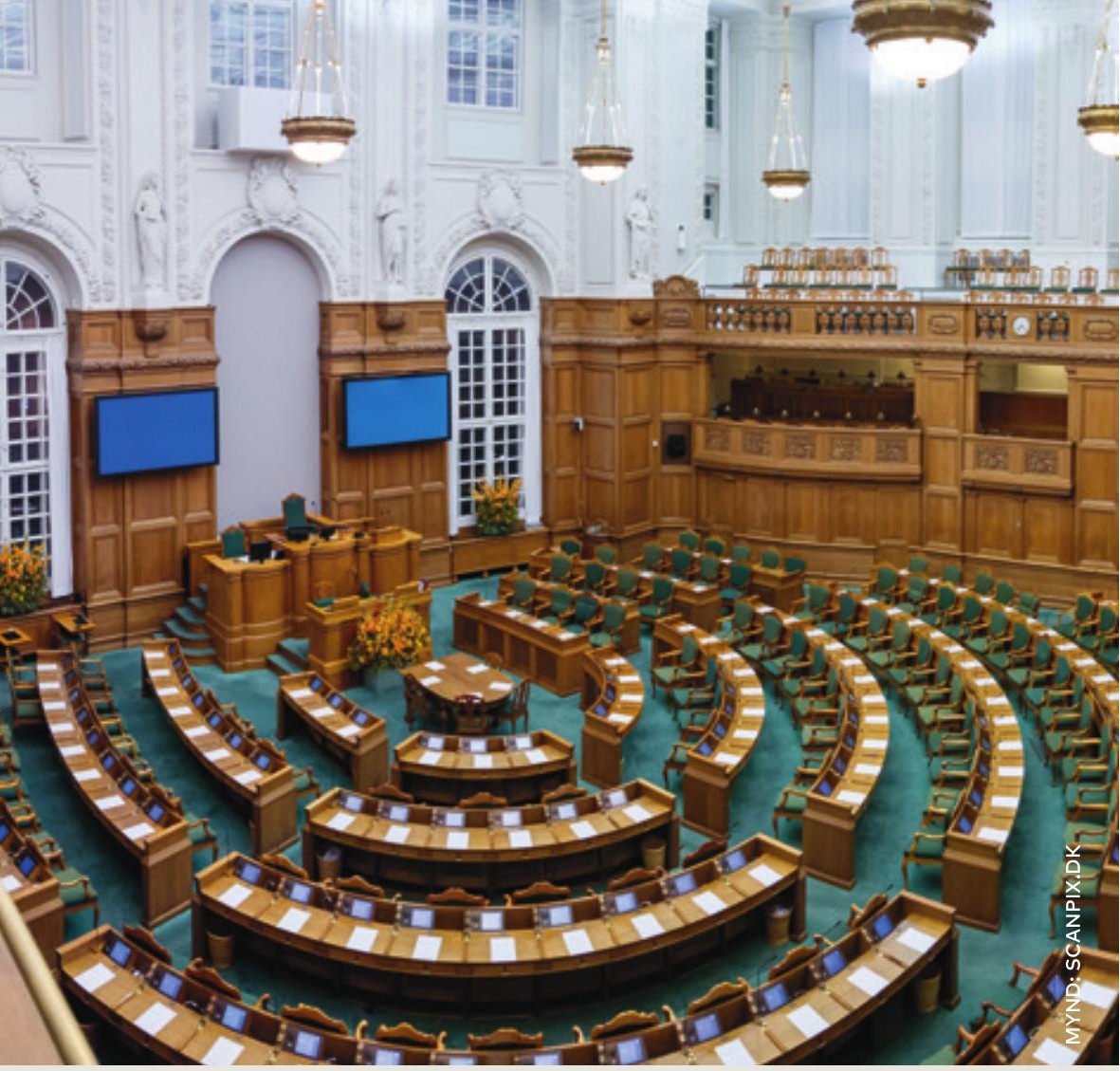

Pemapingið er haldið á hverju vori í einhverju

norrænu landanna. Myndin er frá danska

pinghúsinu í Kaupmannahöfn. 


\section{Starfsárið og starfshættir}

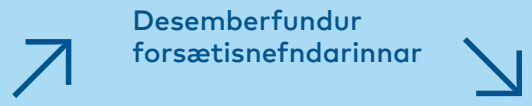

Pingið:

Ákvarðanir um pingmanna-, nefndar-og ráðherranefndartillögur, greinargerðir, skýrslur, fjárhagsáætlun, kjör, ráðherrafundir, fundir með alpjóðlegum fulltrúum

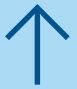

Septemberfundir: Undirbúningur nefndanna vegna mála sem taka á fyrir á pinginu
Janúarfundir:

Samstarfsáætlanir, pema ársins, formennskuáætlun, mál fyrir pemaping

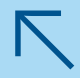

Sumarfundir:

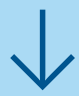

Pemaping + nefndarfundir:

Afgreiðsla mála, svör NMR við tilmælum, hugmyndir um fjárhagsáætlun, málbing, gagnaöflun

Ítarlegri umfjöllun um pema ársins/starfssvið, afgreiðsla svara NMR við tilmælum/ nefndarálit, fjárhagsáætlun

Forsætisnefnd og aðrar nefndir Norðurlandaráðs halda fimm samhliða fundi á ári hverju, par af tvo í tengslum við aðalping og pemaping. Auk pess er einn fundanna haldinn í tengslum við námsferðir forsætisnefndar og fagnefndanna. Sjötti fundur forsætisnefndar er síðan haldinn í lok árs. 
Eftirlitsnefndin, kjörnefndin og aðrir starfshópar halda fundi eftir pörfum. Fundirnir eru yfirleitt haldnir í tengslum við aðra fundi.

Starfsárið hefst með janúarfundunum. Janúarfundirnir eru haldnir í pví landi sem fer með formennsku í Norrænu ráðherranefndinni. Fagnefndirnar fjalla m.a. um starfsáætlanir nefndanna, samskiptaáætlanir og pema ársins og tillögur sem leggja á fyrir pemaping.

Pemapingið er haldið á hverju vori í einhverju norrænu landanna. Fulltrúar ríkisstjórnar viðkomandi lands sitja pingið. Á pemapinginu er fjallað um tiltekið málefni sem er ofarlega á baugi í pví skyni að efla samráð Norðurlandaráðs og Norrænu ráðherranefndarinnar.

Allar nefndir Norðurlandaráðs fara í námsferðir í tengslum við sumarfundina sem eru haldnir hver í sínu lagi ólíkt almennum nefndarfundum sem eru haldnir samtímis og á sama stað. Sumarfundirnir eru yfirleitt haldnir í 26. viku (júní/júlí) og eru pá oft sameinaðir námsferðum nefndanna til staða sem skipta pær máli, oft staða par sem afla má upplýsinga um viðfangsefni nefndanna.

Að loknu sumarfríi hittast nefndirnar á septemberfundum, en pá eru aðallega á dagskrá málefni sem munu verða til umfjöllunar á næsta pingi. 
Árlegt aðalping Norðurlandaráðs er haldið i 44. viku (október/nóvember) í pví landi sem fer með formennsku í ráðinu. Par eru haldnir nefndar- og flokkahópafundir áður en ping hefst, og á meðan á pinginu stendur er haldinn fjöldi funda: samráðsfundir með fagráðherrum, fundir forsætisnefndar með t.d. forsætisráðherrum, utanríkisráðherrum, samstarfsráðherrum, Vestnorræna ráðinu, fulltrúum annarra pjóðpinga o.fl. Sjá nánar um ping Norðurlandaráðs á bls. 15.

Starfsárinu lýkur með desemberfundi forsætisnefndar.

Forsætisnefnd, fagnefndir og aðrar nefndir færa gerðabækur á fundum sínum. Allar ályktanir eru staðfestar á fundinum. Eigi síðar en 14 dögum eftir fundinn er fundargerð send út og hún birt á www.norden.org.

\section{Gerð fjárhagsáætlunar: Norræna ráôherranefndin}

Norræna ráðherranefndin skal sampykkja fjárhagsáætlun fyrir norrænt samstarf í heild og er hún borin undir Norðurlandaráð til staðfestingar. Á grundvelli leiðbeininga um fjárhagsáætlun undirbýr framkvæmdastjóri Norrænu ráðherranefndarinnar tillögu að fjárhagsáætlun sem fer til umfjöllunar í nefndum Norðurlandaráðs og flokkahópum. Norðurlandaráð og Norræna ráðherranefndin fjalla um fjárhagsáætlun fram að Norðurlandaráðspingi par sem nefndarálit um fjárhagsáætlun Norrænu ráðherranefndarinnar er afgreitt á pingfundi með endanlega sampykkt fyrir augum. Norðurlandaráð getur 
lagt til breytingar á forgangsröðun (endurráðstöfun) og krafist nánari skýringa á tilteknum fjárliðum til að tryggja að fénu verði varið á tiltekinn hátt. Fjárhagsramminn sjálfur er óhagganlegur. Í samráði við talsmenn flokkahópanna ber forsætisnefndin ábyrgð á vinnu að fjárhagsáætlun par til hún er lögð fyrir Norðurlandaráð á pinginu í 44. viku. Tilmæli Norðurlandaráðs eru pví næst send til Norrænu ráðherranefndarinnar.

Fjárhagsáætlun næsta árs er endanlega sampykkt af samstarfsráðherrum í desember.

Á sumarfundunum ræða nefndirnar og flokkahóparnir tillögu framkvæmdastjórans að fjárhagsáætlun fyrir næsta ár og talsmenn vegna fjárhagsáætlunar (fulltrúar flokkahópanna) eru að pví loknu upplýstir um pað.

Á septemberfundunum er fjallað um langtímaforgangsröðun fjárhagsáætlunar og talsmenn vegna fjárhagsáætlunar fá upplýsingar um forgangsröðunina fyrir samráð með MR-SAM (Samstarfsráðherrar Norðurlanda) sem yfirleitt fer fram í byrjun árs.

\section{Formennskuáætlun}

Á hverju ári er tekin saman formennskuáætlun pess lands sem fer með formennsku í Norðurlandaráði næsta ár. Markmiðið með formennskuáætluninni er að leggja áherslu á forgangsmál og áherslur í starfi Norðurlandaráðs og norrænu samstarfi. 
Að auki semja fagnefndirnar fjórar eigin starfsáætlanir á hverju ári og samskiptaáætlun.

\section{Fjárhagsáætlun og fjármál}

Forsætisnefnd Norðurlandaráðs gerir árlega fjárhagsáætlun fyrir ráðið. Útgjöld Norðurlandaráðs eru m.a. styrkir til flokkahópa, kostnaður við stjórnsýslu, fundi og ferðalög, faglegt starf nefndanna, túlkun og pýðingar, útgáfumál o.fl. Tekjurnar eru fyrst og fremst framlög frá norrænu ríkjunum samkvæmt skiptireglu sem byggist á hlutdeild í samanlögðum vergum pjóðartekjum landanna.

\section{Fjárhagsáætlanir landsdeildanna}

Hver landsdeild hefur eigin fjárhagsáætlun innan ramma viðkomandi pjóðpings. Fulltrúar í Norðurlandaráði sækja nefndarfundi Norðurlandaráðs og starfsemi landsdeildanna er fjármögnuð af fjárhagsáætlunum landsdeildanna.

\section{Styrkir til flokkahópa}

Styrkjum til flokkahópa er ætlað að standa undir hluta af kostnaði við starfsemi peirra. Um er að ræða grunnupphæð sem er sú sama fyrir alla hópana ásamt tiltekinni upphæð fyrir hvern fulltrúa. Fulltrúar sem standa utan norrænu flokkahópanna fá einungis fulltrúastyrkinn. Forsætisnefndin ákveður upphæð styrkja til flokkahópa í tengslum við sampykkt fjárhagsáætlunar fyrir viðkomandi ár og eins hvernig skipting er milli grunnupphæðar og fulltrúastyrks. 


\section{Mál og afgreiðsla peirra}

Norðurlandaráð hefur ráðgefandi hlutverk gagnvart Norrænu ráðherranefndinni og ríkisstjórnum Norðurlanda. Tækin sem fulltrúar Norðurlandaráðs hafa til umráða eru tillögur og fyrirspurnir. Flokkahópar eða skrifstofur landsdeildanna geta aðstoðað við framsetningu máls áður en pað er sent til skrifstofu Norðurlandaráðs. Skrifstofa Norðurlandaráðs hefur ráðgefandi hlutverk gagnvart nefndunum og fulltrúum nefndanna.

Pólitísk umfjöllun um mál fer fram í fagnefndum og forsætisnefnd. Fulltrúarnir geta m.a. sent skriflegar fyrirspurnir til ríkisstjórna Norðurlanda eða til Norrænu ráðherranefndarinnar, eða lagt fram tillögur, annað hvort á eigin vegum eða í samstarfi við nefnd/flokkahóp. Á pingum Norðurlandaráðs leggur ráðherranefndin fram ráðherranefndartillögur. Tegundir pingmála eru auðkenndar með bókstöfum:

- A-mál: Pingmanna- eða nefndartillögur

- B-mál: Ráðherranefndartillögur eða ríkisstjórnartillögur

- C-mál: Greinargerðir og skýrslur

- D-mál: Svör frá ráðherranefndinni eða ríkisstjórnum norrænu landanna (við tilmælum)

- E-mál: Fyrirspurnir til ríkisstjórna Norðurlanda eða til Norrænu ráðherranefndarinnar 
Að auki er flokkurinn „Skjöl”, sem nær yfir skjöl (greinargerðir og p.h.) sem eru til upplýsingar/umfjöllunar á pinginu, en ekki er ætlunin að taka ákvörðun um.

Aðeins ein nefnd getur borið meginábyrgð á umfjöllun um tiltekna tillögu, en nefndin getur leitað til annarra nefnda, einnar eða fleiri, um að fjalla um hana, eða sent hana til umsagnar innanhúss og byggt niðurstöður á sjónarmiðum sem koma fram.

Allar gerðir mála má senda til skrifstofunnar allt árið um kring. Forsætisnefndin ber formlega ábyrgð á að mál sem berast komi til umfjöllunar í hinum ýmsu nefndum Norðurlandaráðs. Öll formleg mál sem eru til umfjöllunar hjá Norðurlandaráði eiga að fara í gegnum skjaladeild skrifstofu Norðurlandaráðs, sem sér um að réttu ferli sé fylgt og farið sé að tímamörkum.

Málin eru birt jafnóðum í rafrænu skjalasafni á heimasíðunni og skrád í málaskrá sem einnig er birt á www.norden.org.

\section{Pingmanna- og nefndartillögur (A-mál)}

Kjörinn fulltrúi í Norðurlandaráði getur lagt fram pingmannatillögu, forsætisnefnd getur lagt fram forsætisnefndartillögu, nefndir (t.d. eftirlitsnefndin) geta lagt fram nefndartillögu. Allar slíkar tillögur eru kallaðar A-mál. Tillagan parf að vera undirrituð af í pað minnsta einum fulltrúa, varamaður getur einnig verið meðflutningsmaður tillögu. Sumar nefndir koma sér 
upp skýrslugjöfum sem hafa pað hlutverk að kynna sér tiltekin málefni til hlítar og undirbúa síðan stærri mál til umfjöllunar í nefndunum.

Hægt er að senda tillögu í skriflegt umsagnarferli hjá stjórnvöldum og samtökum ílöndunum og norrænum samtökum og stofnunum. Einnig er hægt að efna til munnlegs umsagnarferlis/málstofu í tengslum við nefndarfundi.

Pegar nefnd hefur lokið umfjöllun um nefndartillögur leggur hún fram nefndarálit, sem á að fela í sér rökstudda tillögu um ákvörðun. Tillagan getur falið í sér hvatningu til Norðurlandaráðs um að sampykkja tilmæli til

Norrænu ráðherranefndarinnar eða til einnar eða fleiri ríkisstjórna Norðurlanda í tilteknu máli, eða hvatningu til Norðurlandaráðs varðandi innri málefni, t.d. um starfsreglur Norðurlandaráðs. Nefndarálitið er samið á grundvelli tillögu meirihluta nefndarinnar. Peir fulltrúar sem ekki eru sammála tillögu meirihlutans geta gert fyrirvara um ákvörðun nefndarinnar.

\section{Ráorherranefndartillögur (B-mál)}

Norræna ráðherranefndin, ein eða fleiri ríkisstjórnir á Norðurlöndum, landsstjórn Færeyja, Grænlands (Naalakkersuisut) eða Álandseyja geta lagt fram ráðherranefndartillögur og ríkisstjórnartillögur. Pær geta t.d. varðað framkvæmdaáætlanir, fjárhagsáætlanir o.fl. pessar tillögur eru kallaðar B-mál og liggja yfirleitt fyrir í 
upphafi pings Norðurlandaráðs. Að pví loknu er ferlið eins og varðandi D-mál (sjá eftirfarandi).

\section{Greinargerðir og skýrslur (C-mál)}

Páttur í eftirlits- og eftirfylgnihlutverki Norðurlandaráðs er að fjalla árlega um skýrslur frá ráðherranefndinni.

- C 1 er skýrsla Norrænu ráoherranefndarinnar um norrænt samstarf síðastliðið ár.

- C 2 er verkefna- og fjárhagsáætlun Norrænu rádherranefndarinnar fyrir næsta ár.

- C 3, C 4 og C 5 eru skýrslur ríkisendurskoðanda um ársreikninga og starfsemi Norðurlandaráðs, Norrænu ráðherranefndarinnar og Norræna menningarsjóðsins.

\section{Álit/svör (D-mál)}

Á grundvelli A- og B-mála sampykkir Norðurlandaráð á ári hverju u.p.b. 35 tilmæli, sem beint er til Norrænu ráðherranefndarinnar eða til einnar eða fleiri ríkisstjórna Norðurlanda. Tilmælum sem sampykkt eru á Norðurlandaráðspingi (rekommendationer) er beint til Norrænu ráðherranefndarinnar eða til einnar eða fleiri af ríkisstjórnum Norðurlanda. Tilmæli sem eru sampykkt af forsætisnefnd pegar hún gegnir hlutverki pingfundar á milli pinga (fremstillinger) hafa sama gildi og tilmæli sampykkt á Norðurlandaráðspingi, og er peim einnig beint til Norrænu ráðherranefndarinnar eða til einnar eða fleiri ríkisstjórna Norðurlanda. 
Viðbrögð við tilmælum eru kölluð álit eða svör (D-mál). Ráðherranefndin eða ríkisstjórnirnar eiga að gera grein fyrir (veita svar/álit) hvað pær hafa aðhafst vegna tiltekinna tilmæla. Svörin má veita jafnóðum á milli pinga, pó eigi síðar en fyrir næsta aðalping.

Nefndirnar fara jafnóðum yfir öll svör/álit og semja um pau nefndarálit par sem lagt er mat á pað hvort orðið hafi verið við tilmælunum eða ekki. Á grundvelli matsins er kveðið á um hvort málið teljist endanlega afgreitt eða hvort viðhalda skuli tilmælunum, eða hvort bíða skuli pólítísks samráðs.

Ástæðan fyrir pví að fallið er frá tilmælum er ýmist að ráðherranefndin/ríkisstjórnirnar hafa orðið við peim á fullnægjandi hátt eða að ljóst er að einhverra hluta vegna verði ekki farið að tilmælunum. Nefndin getur einnig valið að leggja fram nýja tillögu/tilmæli, ef upphaflega tillagan pykir úrelt eða áherslubreytingar hafa orðið í áranna rás.

\section{Fyrirspurnir (E-mál)}

Kjörnir fulltrúar, eða varamenn peirra, geta lagt fram fyrirspurnir til ríkisstjórnanna eða Norrænu ráðherranefndarinnar. Fyrirspurn á annað hvort að snúast um norrænt samstarf almennt eða snerta skýrslu eða svar sem fyrirspyrjandi óskar að fá varpað ljósi á. Óheimilt er pví að leggja fram fyrirspurn sem einvörðungu varðar innanríkismál tiltekins lands. Hún á að fela í sér rökstuðning í stuttu máli fyrir pví að fyrirspurnin er lögð fram. 
Fyrirspurnir má leggja fram skriflega allan ársins hring til skrifstofu Norðurlandaráðs sem kemur málinu áfram gegnum skrifstofu framkvæmdastjóra Norrænu ráðherranefndarinnar. Veita skal svör við skriflegum fyrirspurnum eigi síðar en sex vikum eftir að pær eru lagðar fram og eiga pau að vera undirrituð af ráðherra.

Í fyrirspurnatíma á pinginu geta fulltrúar lagt fram munnlegar fyrirspurnir sem ráðherrarnir svara beint á pinginu.

\section{Pólitískt samrád}

Norðurlandaráð og ríkisstjórnir norrænu landanna hafa samkvæmt samkomulagi frest til að svara nýjum tilmælum skriflega.

Ef Norðurlandaráð kýs að viðhalda tilmælum hefst pólitískt samráð milli fulltrúa ráðherranefndarinnar og Norðurlandaráðs pegar ágreiningur er um pau. Samráðið getur farið fram á pingum eða í hlutaðeigandi nefnd Norðurlandaráðs. Að loknu pólitísku samráði er litið svo á að tilmælin séu endanlega afgreidd. Ef vilji er til að viðhalda málinu parf að vekja máls á pví með nýjum tilmælum sem getur fyrst orðið á næsta fjárhagsári.

Pólitískt samráð getur farið fram í sambandi við ráðherranefndarfund, ping Norðurlandaráðs, nefndarfund eða samráðsfund í samræmi við eðli tilmælanna. 
Að loknu pólitísku samráði semja nefndir Norðurlandaráðs endanlegt nefndarálit. Pað er staðfest af pingfundinum eða forsætisnefndinni, og pví næst er ráðherranefndin upplýst um hvort talið sé að afgreiðslu málsins/tilmælanna sé lokið.

\section{Ákvarðanir}

Norðurlandaráð afgreiðir formleg mál með ólíkum gerðum ákvarðana:

- Tilmælum er beint til Norrænu ráðherranefndarinnar eða ríkisstjórna Norðurlanda á grundvelli pingmannatillögu, nefndartillögu eða ráðherranefndartillögu (A- eða B-mál).

- Ákvörơunum um innri málefni er beint til Norðurlandaráðs og geta pær t.d. varðað starfsreglur eða önnur mál er varða stjórnsýslu. Pær eru teknar á grundvelli forsætisnefndartillögu.

- Að að̆hafast ekkert frekar, pegar ekki er vilji til að halda áfram með tiltekna tillögu, p.e.a.s. að málið fellur niður án pess að pað hafi leitt til tilmæla eða ákvörðunar um innri málefni.

- Ákvörðun um að færa mál til bókar og bíða eftir pólitísku samrádi (að hluta eða í heild), er beitt pegar svar frá ráðherranefndinni eða ríkisstjórnum norrænu landanna er ekki fullnægjandi eða álitið er að ekki hafi verið farið að tilmælum. 
- Ákvörðun um að Norðurlandaráð telji meðferð tilmæla lokið̃ af hálfu ráósins (að hluta eða í heild), er beitt pegar litið er svo á að tilmælunum hafi verið fylgt eða pau framkvæmd á fullnægjandi hátt (eða ef ráðið telur að ekki sé raunhæft að peim verði fylgt). 


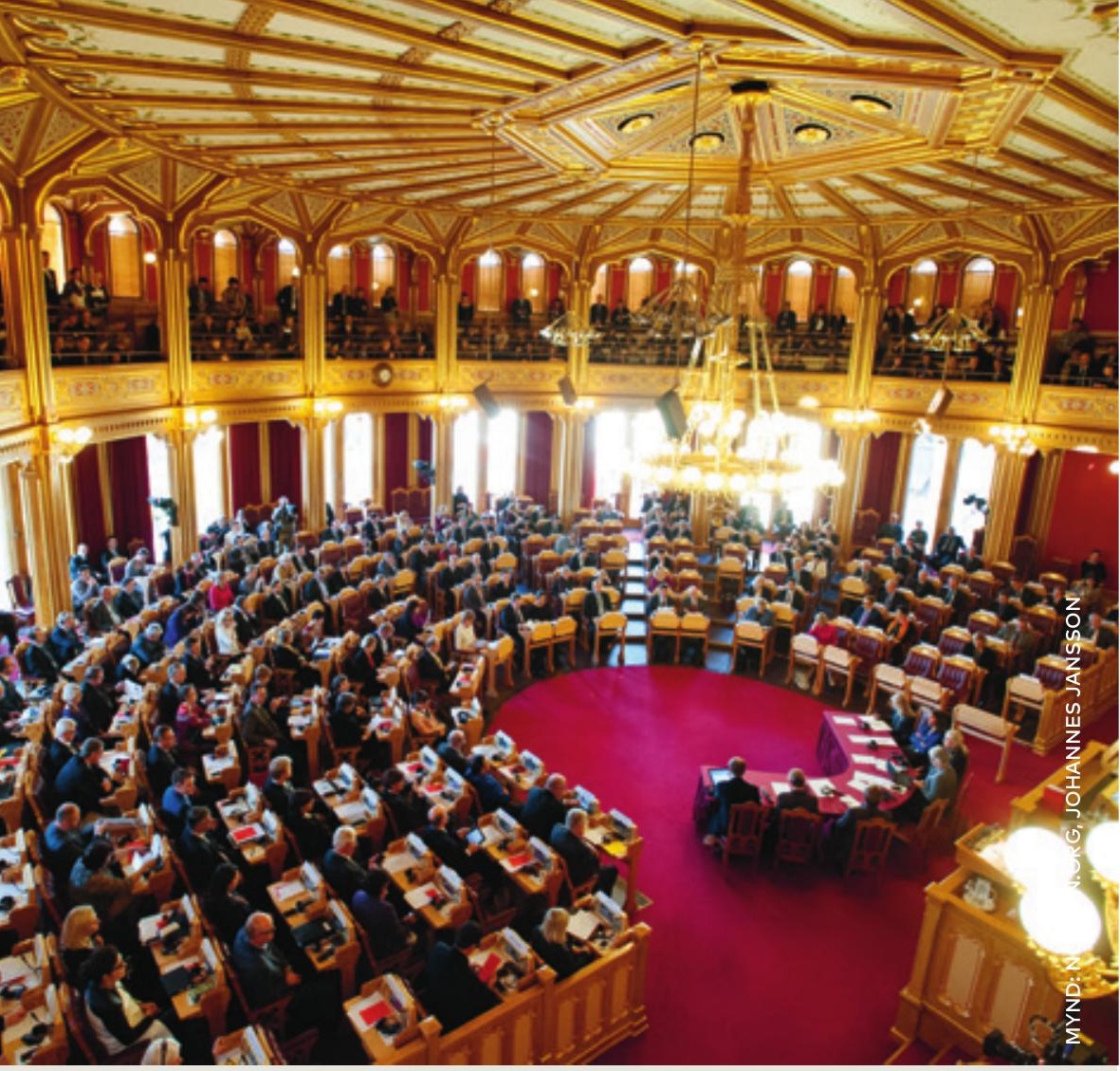

Löndin skiptast á að fara með formennsku Norrænu ráðherranefndarinnar eitt ár í senn í sömu röð og viðhöfð er í Norðurlandaráði, pó ekki á sama tíma. Myndin er frá norska Stórpinginu í Ósló. 


\section{Norræna ráôherranefndin}

Norræna ráðherranefndin (NMR) var stofnuð árið 1971 og er opinber samstarfsvettvangur norrænu ríkisstjórnanna en er pó ekki yfirpjóðleg. Færeyjar, Grænland og Álandseyjar taka einnig pátt í starfi ráðherranefndarinnar.

Löndin skiptast á að fara með formennsku Norrænu ráðherranefndarinnar eitt ár í senn í sömu röð og viðhöfð er í Norðurlandaráði, pó ekki á sama tíma. Pað land sem fer með formennsku Norrænu ráðherranefndarinnar hverju sinni semur áætlun sem er rádgefandi fyrir norrænt samstarf pað árið.

Forsætisráðherrarnir bera meginábyrgð á norrænu samstarfi, en í raun er ábyrgð á samræmingu falin samstarfsráðherrum Norðurlanda (MR-SAM). Hver ríkisstjórn/landsstjórn tilnefnir samstarfsráðherra Norðurlanda fyrir hönd ríkisstjórnarinnar sem auk eigin ráðuneytis ber ábyrgð á samræmingu norræns samstarfs fyrir hönd ríkisstjórnanna. MR-SAM ber ábyrgð á fjárhagsáætlun Norrænu ráðherranefndarinnar og á fjölda pverfaglegra samstarfsverkefna hjá ráðherranefndinni. Norræna samstarfsnefndin (NSK) er samstarfsráðherrunum til aðstoðar og sér um samræmingu opinbers pólitísks samstarfs Norðurlanda. Í NSK eiga sæti embættismenn frá utanríkisráðuneytum landanna ásamt Færeyjum, Grænlandi og Álandseyjum og er nefndin einnig stjórn skrifstofu ráðherranefndarinnar. 
Norræna ráðherranefndin er í raun margar ráðherranefndir, p.e. fagráðherranefndir, auk samstarfsráðherranefndar. Fagráðherranefndirnar hittast tvisvar á ári. Ákvarðanir í norrænu ráðherranefndunum skulu sampykktar einróma. Á vegum ráðherranefndanna starfa embættismannanefndir, skipaðar embættismönnum frá ríkjunum. Pær undirbúa og fylgja eftir málum sem eru til umfjöllunar á norrænum vettvangi.

Forsætisráðherrar Norðurlanda hittast á árlegum fundum og hittast auk pess á öðrum vettvangi, t.d. í sambandi við leiðtogafundi ESB. Norrænir utanríkis- og varnarmálaráðherrar hittast einnig reglulega á öðrum vettvangi.

\section{Skrifstofa ráoherranefndarinnar}

Skrifstofa Norrænu ráðherranefndarinnar í Kaupmannahöfn ber ábyrgð á daglegum rekstri samstarfs norrænu ríkisstjórnanna. Skrifstofan ber ábyrgð á pví að sampykktar ákvarðanir komist i framkvæmd og að undirbúa mál sem eru tekin upp í hlutaðeigandi ráðherranefndum og í embættismannanefndunum. Sjá nánar um ráðherranefndir og aðrar nefndir á www.norden.org.
Á skrifstofu ráðherranefndarinnar starfa u.p.b. 115 starfsmenn og er hún undir stjórn framkvæmdastjóra. Skrifstofa framkvæmdastjórans (GSK) ber einnig ábyrgð á samstarfi Norrænu ráðherranefndarinnar (NMR) og Norðurlandaráðs og samræmir jafnóðum svör við 
tilmælum og skriflegum fyrirspurnum sem berast frá Norðurlandaráði (NR).

Skrifstofa framkvæmdastjórans samræmir og skipuleggur fundi og mál sem samstarfsráðherrar Norðurlanda (MR-SAM) og Norræna samstarfsnefndin (NSK) hyggjast taka upp. Önnur starfsemi ráðherranefndarinnar er undirbúin á hverju fagsviði fyrir sig. 


\section{Skrifstofur landsdeilda Norðurlandaráðs}

Nordisk Råd

Den danske delegation

Christiansborg

DK-1240 København K, Danmark

Sími: +45 33375999

nr@ft.dk

Norðurlandaraðið

Færøernes Lagting

Postbox 208

FO-110 Tórshavn, Færøerne

Sími: +298 363900

nr@logting.fo

Nordisk Råd

Grønlands delegation

Bureau for Inatsisartut

Postboks 1060

GL- 3900 Nuuk, Grønland

Sími: +299345000

inatsisartut@inatsisartut.gl

Nordiska rådet/Pohjoismaiden neuvosto

Finlands delegation

Riksdagshuset

FI-00102 Helsinki, Finland

Sími: +35894321

int.dep@eduskunta.fi 
Nordiska rådet

Ålands delegation

Ålands Lagting

PB 69

AX-220 101 Mariehamn, Åland

Sími: +358 1825474

maj.falck@lagtinget.ax

Norðurlandaráð

Íslandsdeild

Alpingi

IS-150 Reykjavík, Íslandi

Sími: +3545630448

nr@althingi.is

Nordisk råd

Den norske delegasjon

Stortinget

NO-0026 Oslo, Norge

Sími: +47 23313050

nordpost@stortinget.no

Nordiska rådet

Svenska delegationen

Riksdagen

SE-100 12 Stockholm, Sverige

Sími: +4687864000

nr@riksdagen.se

Norðurlandaráð

Ved Stranden 18

DK-1061 København K

Sími: +45 33960400

nordisk-rad@norden.org 

Norðurlandaráð

Ved Stranden 18

DK-1061 København K

www.norden.org

ANP 2017:715

ISBN 978-92-893-4875-1 (PRINT)

ISBN 978-92-893-4876-8 (PDF)

ISBN 978-92-893-4942-O (EPUB) 